\section{Can Long-term Antifungal Therapy Be an Alternative to Surgery in Pulmonary Aspergilloma?*}

\author{
Pulmoner Aspergillomada Uzun Dönem \\ Antifungal Tedavi Cerrahiye Alternatif Olabilir mi?
}

\begin{abstract}
Pulmonary aspergilloma is one of the clinical conditions with high mortality and morbidity in immunosuppressed patients. Surgical resection has been the leading treatment option; however, surgical treatment involves some risk of local and systemic dissemination and there are also patients who are functionally inappropriate to be treated surgically. In this paper, we present two patients with bilateral PA who underwent surgical and antifungal treatment. Antifungal therapy with voriconazole that was successful for both of our patients might be a promising approach to a group of PA patients who are not appropriate for surgery.
\end{abstract}

Keywords: pulmonary aspergilloma; voriconazole; surgery; fungus ball

Öz

Pulmoner aspergilloma (PA), immünsüprese hastalarda yüksek mortalite ve morbiditeli klinik durumlardandır. Tedavide sıklıkla cerrahi rezeksiyon tercih edilir; fakat cerrahide lokal ve sistemik yayılım riski mevcuttur ve ayrıca cerrahi tedaviye fonksiyonel olarak uygun olmayan hastalar da vardır. Bu çalışmada cerrahi ve antifungal tedavi uygulanmış olan bilateral PA'ı iki hastayı sunmaktayız. Vorikonazol ile yapılan ve iki hastamızda da başarılı olan antifungal tedavi, cerrahiye uygun olmayan bir grup PA hastası için ümit verici bir yaklaşım olabilir.

Anahtar Sözcükler. pulmoner aspergilloma; vorikonazol; cerrahi; mantar topu
H. Volkan Kara', Ezel Ersen', Mehlika Iscan', İsmail Sarbay' Merve Ekinci' ', Akif Turna'

Istanbul University, Cerrahpasa Medical Faculty, Department of

Thoracic Surgery, Istanbul, Turkey

Geliş Tarihi /Received : 06.04.2018 Kabul Tarihi /Accepted: 27.04.2018

DOI: 10.21673/anadoluklin.413147

Sorumlu Yazar/Corresponding Author

H. Volkan Kara

Esenevler Mah., Yunusemre Cad., Devran

Sok. 15-8, Ümraniye, İstanbul

E-mail: volkan_kara@yahoo.com 


\section{INTRODUCTION}

Pulmonary aspergilloma (PA) is the saprophytic colonization of Aspergillus fumigatus in the existing cavities of the lung parenchyma $(1,2)$. Especially in immunosuppressed patients (with a history of bone marrow transplantation, malignant hematological disorders, high-dose use of corticosteroids, or chemotherapeutic regimens), pulmonary aspergillosis may cause clinical outcomes with high morbidity and mortality (1-4). Aspirated aspergillus spores proliferate and turn into invasive hyphae in patients with impaired phagocytic functions that progress to broncho- and/or angio-invasive aspergillosis in deep immunosuppression or to mycetoma/fungus ball in mild to moderate immunosuppression. Invasive aspergillosis and mycetoma usually have different clinical courses (1-4).

Hemoptysis is the major life-threatening acute clinical condition caused by PA. There is also some risk of developing invasive aspergillosis or fungal septicemia, which have even higher morbidity and mortality $(5,6)$. Treatment and follow-up of patients with PA still lack a well-defined evidence-based algorithm. Surgery has been the leading treatment option in current practice $(1,7)$; however, it also involves some risk of local or systemic dissemination, resulting in invasive aspergillosis or fungemia $(2,6)$. Adjuvant use of mold-active antifungal drugs has been shown to be effective for preventing dissemination $(8,9)$, despite the contrary feedbacks regarding its use involving systemic side effects with unexpectedly low prevention benefits (1).

In this paper we present two cases of bilateral PA. Bilateral surgical excision had been planned for both patients, who received adjuvant antifungal treatment after the operation for their lesions on one side. The patients' lesions on the non-operated side regressed during the follow-up period, eliminating the need for further surgery.

\section{Case 1}

A 56-year-old female patient had had diagnosed sarcoidosis for the last 3 years. She was an active smoker and had been smoking 20 packs of cigarettes per year. For the last 7 months, corticosteroids were added to her treatment. She had a sudden attack of hemoptysis with dyspnea and productive cough. In the chest
X-Ray, a cavitary lesion located on the left lung and suspicious infiltration in the right lung were seen (Figure 1a). Computerized tomography (CT) of the thorax revealed a $4 \times 3-\mathrm{cm}$ cavitary lesion with a thick wall. A lobulated soft tissue density as a mycetoma-fungus ball was also detected inside this cavitary lesion. In the right lung there were infiltrative areas (Figure 1b). The fiber-optic bronchoscopic examination revealed bleeding from the left upper lobe without any additional pathology in the airway. In the Giemsa stain of bronchoalveolar lavage (BAL), there were polymorphonuclear leukocytes and bronchial epithelial cells. BAL and sputum culture yielded normal oral flora with no signs of fungal elements in the Gram and Giemsa staining. As the hemoptysis of the patient progressed, we performed a left upper lobectomy by a left anterior thoracotomy to avoid any life-threatening condition. The postoperative period was uneventful and the patient was discharged on the $6^{\text {th }}$ postoperative day. The histopathological examination revealed mycetoma in the bronchiectasis areas in the lung parenchyma. The patient did very well during the postoperative period and had no hemoptysis. In the $15^{\text {th }}$ month there was a new episode of hemoptysis and dyspnea. Radiological evaluation showed a recurrence of a cavitary lesion in the existing left lower lobe. There was also a bronchopleural fistula (BPF) and newly developed cavitary lesions in the bacillary segments of the right lower lobe. Antifungal treatment with IV voriconazole (loading dose 6 $\mathrm{mg} / \mathrm{kg}$, maintenance dose $4 \mathrm{mg} / \mathrm{kg} \mathrm{q} 12 \mathrm{~h}$ ) was initiated and surgery was planned for the patient. We performed anterolateral thoracotomy and the cavitary lesion inside the thoracic cavity was resected. The BPF was also repaired via thoracomyoplasty by excising 3 ribs, with a muscle flap placed in the thoracic cavity. The postoperative period was uneventful and the patient was discharged on the 7th postoperative day (Figure 1c). The physical and mental condition of the patient was not appropriate for the contralateral surgery. Accordingly, it was decided to continue antifungal treatment with voriconazole $(2 \times 200 \mathrm{mg}$ per oral). No voriconazole-related side effect was observed during the following 6 months of treatment. The follow-up computed tomography (CT) scan of the thorax showed a total regression of the cavitary lesion in the right lung, which turned into a soft tissue remnant (Figure 1d). 


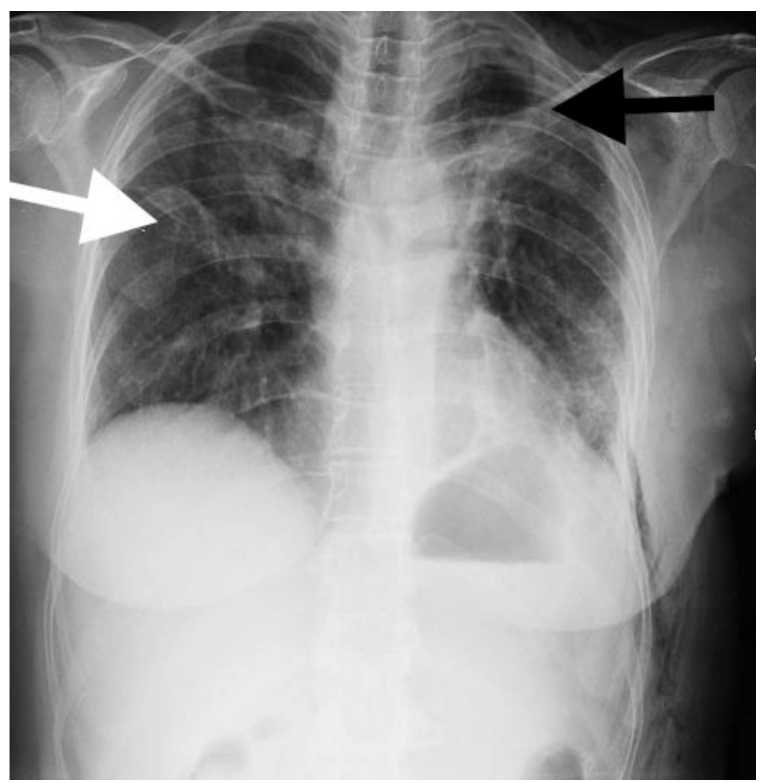

Figure 1a. Chest X-ray showing a cavitary lesion on the left upper zone (black arrow) and a suspicious infiltrative lesion on the right middle zone (white arrow).

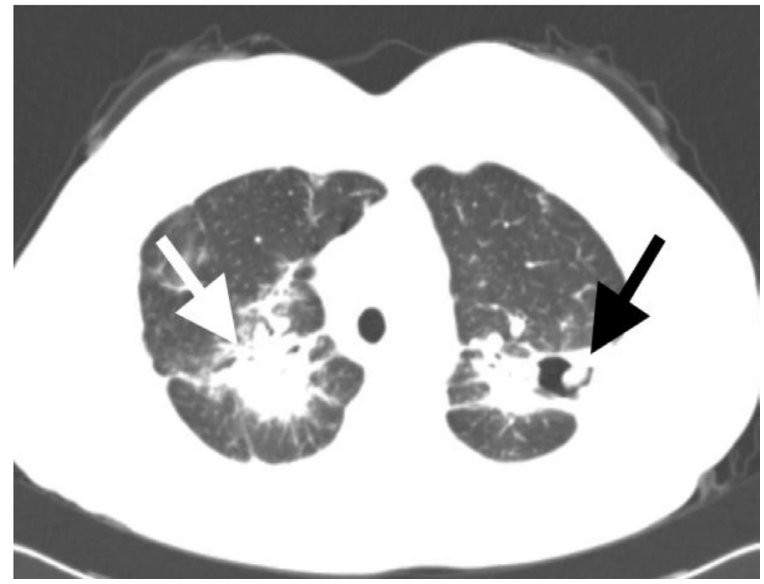

Figure $1 \mathrm{~b}$. CT of the chest revealed a $4 \times 3-\mathrm{cm}$ cavitary lesion with a thick wall in the left lung. Inside the lesion there was a $1 \mathrm{x} 1-\mathrm{cm}$ lobulated soft tissue surrounded with infiltration (black arrow). There was an infiltrative pre-cavitary area in the right middle lobe (white arrow).

\section{Case 2}

A 53-year-old female patient with acute myeloid leukemia (AML) for 4 years was re-hospitalized for chemotherapy due to disease recurrence on the $4^{\text {th }}$ day of the treatment, and she had febrile neutropenia. Blood, urine and sputum cultures did not confirm any bacterial growth. Her chest X-ray revealed clear diffuse infiltration in the left lung, compatible with opportunistic fungal pneumonia, particularly invasive pulmonary aspergillosis (Figure 2a). The serum galac-

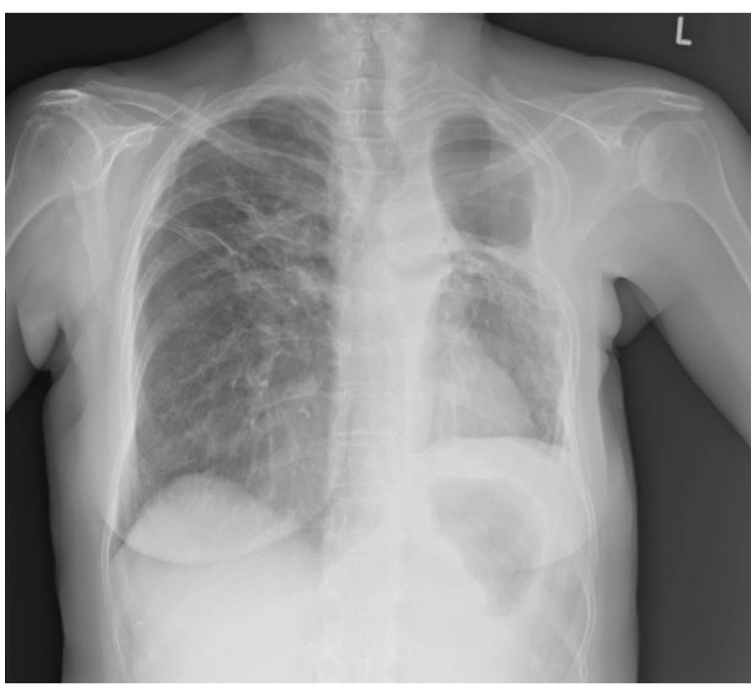

Figure 1c. Chest X-ray after bronchopleural fistula repair surgery. Thoracomyoplasty by excising 3 ribs was performed and a muscle flap was placed in the left hemithorax.

tomannan test (Aspergillus antigen) was positive. She was under fluconazole prophylaxis since the onset of her chemotherapy. The regimen was shifted to a moldactive antifungal with liposomal amphotericin-B 3 $\mathrm{mg} / \mathrm{kg} / \mathrm{d}$ IV upon infectious diseases consultation. Despite this treatment her fever continued and she had hemoptysis on the $6^{\text {th }}$ day. CT of the chest showed a centrally located cavitary lesion in the left lung lingula section. The lesion had a diameter of $3,5 \mathrm{~cm}$ and was surrounded with ground-glass opacities. In the right lung there were similar nodular and cavitary lesions suspected to be aspergilloma (Figure2b). L-AmphB

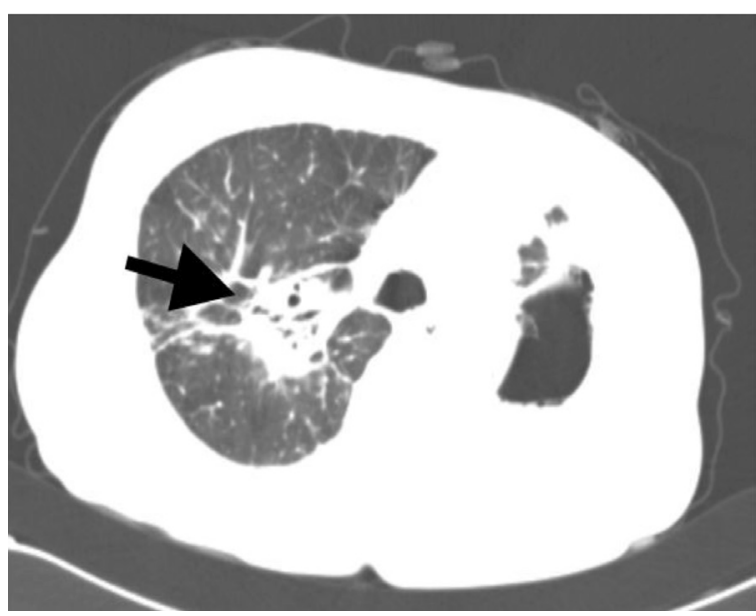

Figure 1d. CT of the chest revealed that the previously defined lesion in the right lung regressed and turned into a soft tissue density area (black arrow), with secondary changes due to the previous interventions in the left hemithorax. 
was switched to voriconazole (200mg q12h IV), which is superior to other antifungals against aspergillus species. As the hemoptysis continued, she had FOB, with an active bleeding from the left lingular bronchus. As the symptoms persisted and the patient needed chemotherapy for her AML, a surgical resection was planned. We performed a uniportal video-assisted thoracoscopic surgery (VATS) left lingulectomy. The postoperative course was uneventful and the patient's chest tube was pulled off before her discharge on the $2^{\text {nd }}$ postoperative day. The patient continued her antifungal treatment with voriconazole $(2 \times 200 \mathrm{mg}$ per oral). The initial plan was surgical excision for the right side and accordingly the patient had a CT thorax scan in the $5^{\text {th }}$ week. The CT scans showed that the pre-existing lesions on the right almost totally regressed. This made a change in our surgical plan for the right side, and we decided to follow up the patient under antifungal treatment. In the $4^{\text {th }}$ month she was quite fine clinically and the disease appeared radiologically to have regressed (Figure 2d).

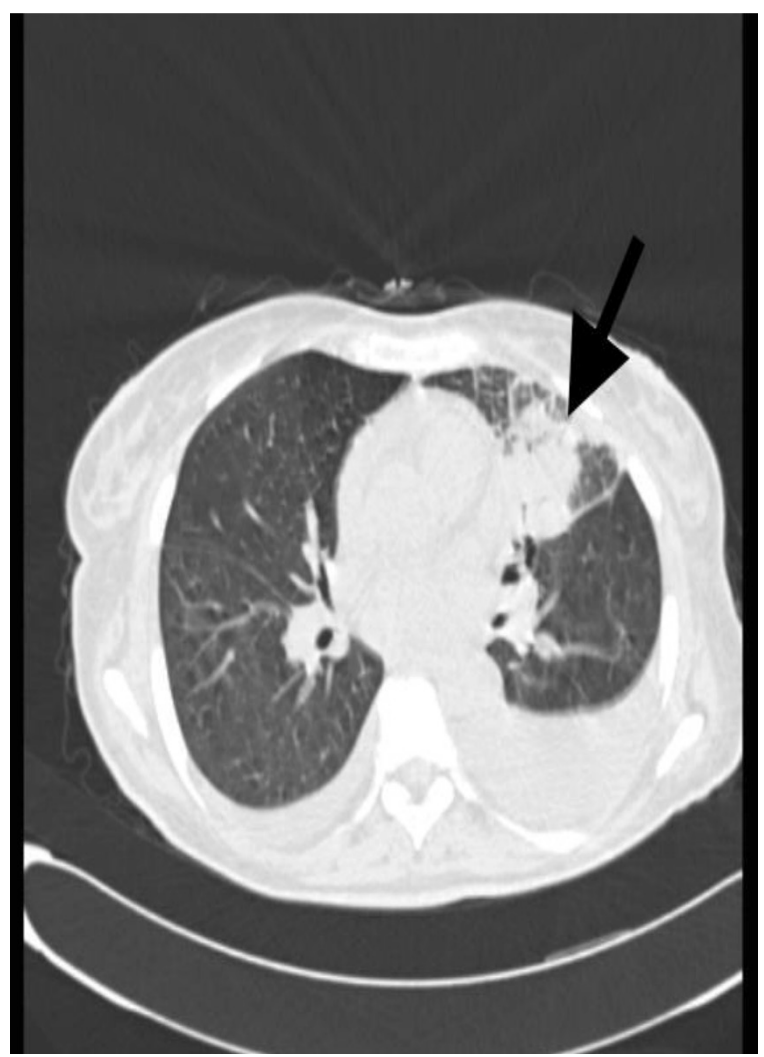

Figure 2a. CT of the chest revealed a 2,5-cm cavitary nodular lesion in the left upper lobe (black arrow).

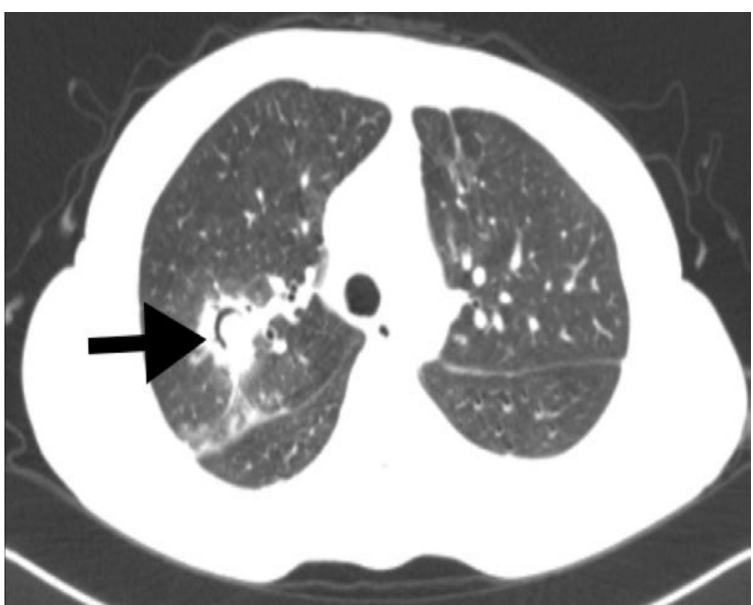

Figure $\mathbf{2 b}$. CT of the chest showing a $3-\mathrm{cm}$ ground-glass opacity lesion with a cavitary component in the right hemithorax (black arrow).

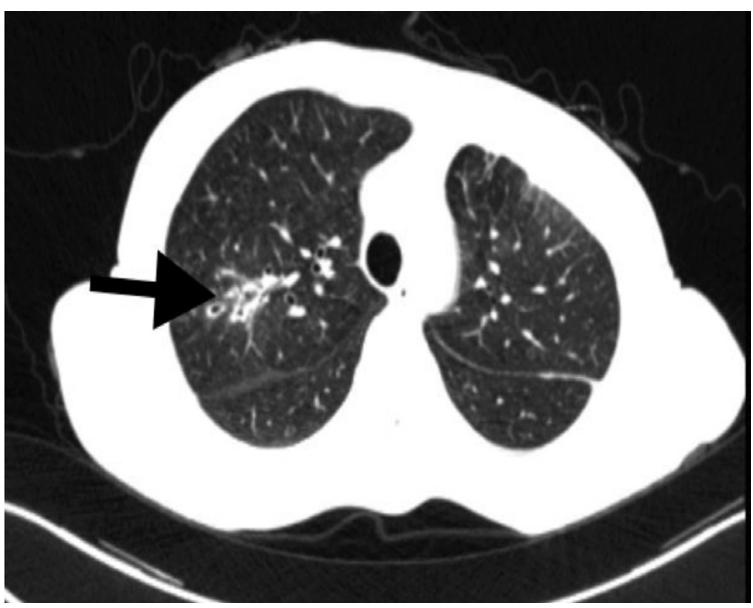

Figure 2c. The follow-up CT scan prior to the second surgery showed regression in the pre-existing cavitary lesions in the right lung.

\section{RESULTS}

The cavitary lesions on the non-operated sides regressed nearly totally in both patients. No prominent side effect related to the antifungal treatment was observed. Patient 1 is in the $41^{\text {st }}$ and Patient $25^{\text {th }}$ month of follow-up, with no clinical problem due to PA. Their primary diseases (sarcoidosis and AML) are also clinically under control.

\section{DISCUSSION AND CONCLUSION}

Aspergillus fumigatus is one of the most common fungal pathogens for invasive pulmonary infections in immunosuppressed patients $(1-3,10)$. Because there is 


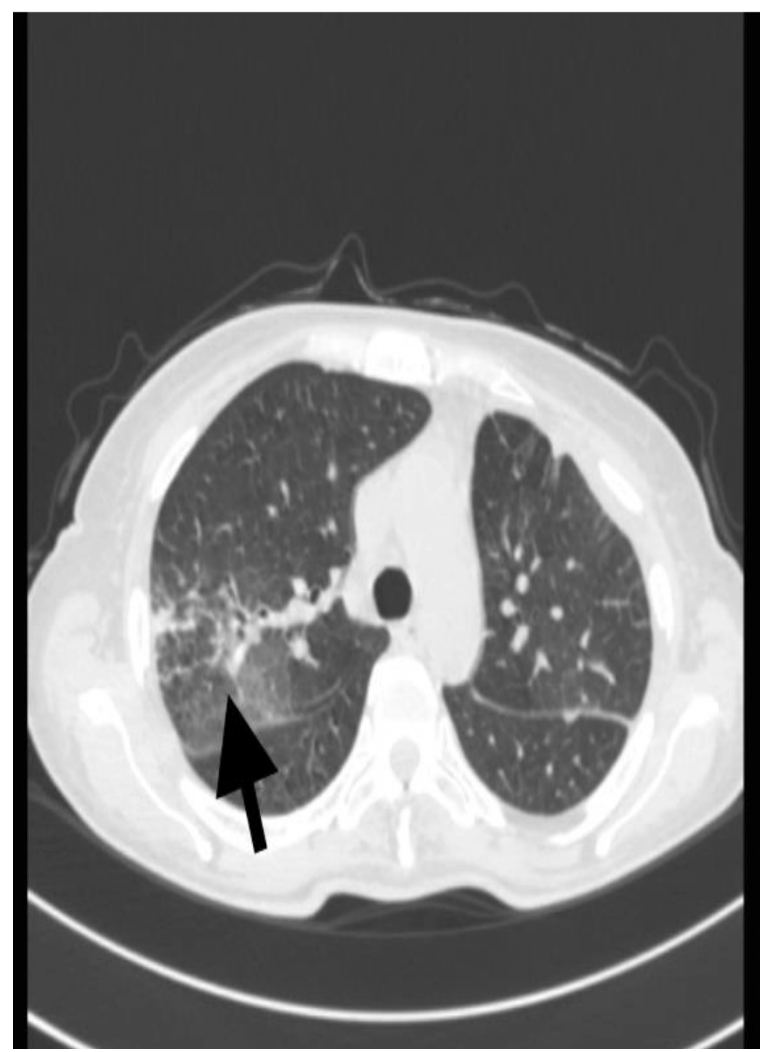

Figure 2d. In the $4^{\text {th }}$ month of antifungal treatment CT of the chest confirmed that the regression in the right lung was steady.

an ongoing construction process in our hospital and fungal spores are easily spread via air flow, the risk of exposure is extremely high for all patients regardless of inpatient or outpatient setting. The most common clinical form of aspergillus infection in respiratory system is invasive pulmonary aspergillosis (IPA) in immunosuppressed patients, particularly those with hematological cancer. Pulmonary aspergilloma is also common in patients with mild to moderate immunosuppression. (10). PA may develop inside the cavities secondary to localized emphysema, sarcoidosis, bronchiectasis, tuberculosis-related bullae, cystic lesions, or cavities formed by necrotizing infections. Among those, pulmonary tuberculosis is the leading cause for cavity formation with a rate of $11 \%$ (11). Aspergillus spores may remain silent within the alveoli for years and reactivate in case of neutropenia due to cytotoxic treatment. The most common symptoms are fever, productive cough and hemoptysis, which is a sign of vessel invasion $(1,3)$ With a mortality of up to $50 \%$, hemoptysis is the most serious clinical condition requiring urgent attention $(4,13-15)$. Surgery is preferred in cases of aspergilloma (so-called "fungus ball") where medical treatment is less effective. However the surgical procedure itself has a mortality of 1 to $22 \%$ and morbidity 23 to $78 \%$ (16-19). Use of moldactive adjuvant (prior to and after surgery) antifungal treatment has not been proven to be superior to surgery alone (1). Also some groups of patients may not be good candidates for surgery due to their existing risks or poor functional lung capacity. Accordingly, alternative evidence-based treatment options are needed.

In conclusion, both of our patients had bilateral PA and underwent unilateral surgery. The first patient was not appropriate for the contralateral surgery due to impaired lung function and the second was in the waiting period. Both showed a dramatic regression in their cavitary lesions with adequate antifungal treatment. Long-term outpatient use of voriconazole that was successful for both of our patients might be a promising approach to a group of PA patients who are not appropriate for surgery, although our results need to be supported by further research.

\section{REFERENCES}

1. Sagan D, Goździuk K. Surgery for pulmonary aspergilloma in immunocompetent patients: no benefit from adjuvant antifungal pharmacotherapy. Ann Thorac Surg. 2010;89(5):1603-10.

2. Lee JG, Lee CY, Park IK, et al. Pulmonary aspergilloma: analysis of prognosis in relation to symptoms and treatment. J Thorac Cardiovasc Surg. 2009;138:820-5.

3. Brik A, Salem AM, Kamal AR, et al. Surgical outcome of pulmonary aspergilloma. Eur J Cardiothorac Surg. 2008;34:882-5.

4. Park CK, Jheon S. Results of surgical treatment for pulmonary aspergilloma. Eur J Cardiothorac Surg. 2002;21:918-23.

5. Campbell JH, Winter JH, Richardson MD, Shankland GS, Banham SW. Treatment of pulmonary aspergilloma with itraconazole. Thorax. 1991;46:839-41.

6. Seki M, Maesaki S, Hashiguchi K, et al. Aspergillus fumigatus isolated from blood samples of a patient with pulmonary aspergilloma after embolization. Intern Med. 2000;39:188-90.

7. Jewkes J, Kay PH, Paneth M, Citron KM. Pulmonary aspergilloma: analysis of prognosis in relation to haemopt- 
ysis and survey of treatment. Thorax. 1983;38:572-8.

8. Ho KM, Lipman J, Dobb GJ, Webb SA. The use of prophylactic fluconazole in immunocompetent high-risk surgical patients: a meta-analysis. Crit Care. 2005;9:R710-7.

9. Calandra T, Marchetti O. Clinical trials of antifungal prophylaxis among patients undergoing surgery. Clin Infect Dis. 2004;39(suppl 4):S185-92.

10. Scott SM, Takara T, Varkey B, et al. Thoracic mycotic and actinomycotic infections. In: W. Shields (ed.), General Thoracic Surgery. Baltimore: Williams and Wilkins; 1994:986.

11. British Thoracic and Tuberculosis Association. Aspergilloma and residual tuberculous cavities: the results of re-survey. Tubercle. 1970;51:227-45.

12. Odev K. Toraks Radyolojisi, 2. ed. Nobel Tip Kitabevleri; 2010:214-5.
13. Jewkes J, Kay PH, Paneth M, Citron KM. Pulmonary aspergilloma: analysis of prognosis in relation to haemoptysis and survey of treatment. Thorax. 1983;38:572-8.

14. el Oakley R, Petrou M, Goldstraw P. Indications and outcome of surgery for pulmonary aspergilloma. Thorax. 1997;52:813-5.

15. Herbrecht R, Denning DW, Patterson TF, et al. Voriconazole versus amphotericin $B$ for primary therapy of invasive aspergillosis. N Engl J Med. 2002;347(6):408-15.

16. Babatasi G, Massetti M, Chapelier A, et al. Surgical treatment of pulmonary aspergilloma: current outcome. J Thorac Cardiovasc Surg. 2000;906-12.

17. Regnard JF, Icard P, Nicolasi M, et al. Aspergilloma: a series of 89 surgical cases. Ann Thorac Surg. 2000;69:898903. 